\title{
Changes in platelet and leukocyte parameters during pregnancy in women with spontaneous pre-term delivery.
}

\author{
Rongli Xu' ${ }^{1}$, Baohua Wu ${ }^{1}$, Jinghua Chen ${ }^{2}$ and Jianying Yan ${ }^{1}$ \\ ${ }^{1}$ Department of Obstetrics, Fujian Maternity and Child Health Hospital, Affiliated \\ Hospital of Fujian Medical University, Fuzhou, Fujian, China. \\ ${ }^{2}$ Department of Obstetries, Fujian Medical University Union Hospital, Fujian, China.
}

Key words: spontaneous preterm birth; platelet parameters; leukocyte parameters.

\begin{abstract}
This study analyzed, retrospectively, the changes of platelet and leukocyte parameters in pregnant women with spontaneous preterm birth. A group of 1050 single embryo pregnant women, who underwent regular obstetric examination and in-patient delivery, were divided into three groups: a preterm birth group, a threatened preterm birth group (at admission) and a full-term group. The platelet parameters [platelet count (PLT), mean platelet volume (MPV), plateletcrit (PCT), platelet distribution width (PDW)] and leukocyte parameters [white blood cell count (WBC), neutrophil to lymphocyte ratio (NLR), lymphocyte to monocyte ratio (LMR), platelet to lymphocyte ratio (PLR)] were compared in each group. PLT and MPV in preterm birth women were higher than those in the full-term and threatened preterm birth group. Throughout pregnancy, the platelet count showed the lowest level at delivery. The NLR in the preterm group was higher than in the full-term and threatened preterm groups at admission, and the PLR was higher than in the full-term group. The NLR increased gradually during pregnancy, and reached its peak in the full-term group one week before delivery. NLR in the threatened preterm group and preterm group reached their peak in late pregnancy. A BP (back propagation) artificial neural network model was constructed with significant PLT, MPV, NLR and PLR as input values in a univariate analysis. The AUC for predicting the risk of preterm birth using the ROC curve evaluation model was 0.819 . In conclusion, the elevation of PLT, MPV, NLR and PLR in pregnant women is related to spontaneous preterm birth. The BP artificial neural network model has certain predictive value for spontaneous preterm birth.
\end{abstract}

Corresponding Author: Jianying Yan. Department of Obstetrics, Fujian Maternity and Child Health Hospital, Affiliated Hospital of Fujian Medical University, Fuzhou, Fujian, China. Tel: +86 0591-86329265. E-mail: y_ying007@aliyun.com 


\title{
Cambios en los parámetros plaquetarios y leucocitarios durante el embarazo en mujeres con parto prematuro espontáneo.
}

\author{
Invest Clin 2020; 61 (1): 28-38
}

Palabras clave: parto prematuro espontáneo; parámetros plaquetarios; parámetros leucocitarios.

\begin{abstract}
Resumen. Este estudio analizó retrospectivamente los cambios de parámetros plaquetarios y leucocitarios en mujeres embarazadas con parto prematuro espontáneo. Un grupo de 1050 mujeres embarazadas con un solo embrión, quienes se sometieron a exámenes obstétricos regulares y a un parto intrahospitalario, se dividieron en tres grupos, de acuerdo a la fecha del trabajo de parto: un grupo prematuro, un grupo de amenaza de parto prematuro (en la admisión) y un grupo a término. Los parámetros plaquetarios [cuenta plaquetaria (PLT), volumen medio plaquetario (MPV), plaquetocrito (PCT), ancho de distribución plaquetaria (PDW)] y parámetros leucocitarios [cantidad de glóbulos blancos (WBC), relación de neutrófilos a linfocitos (NLR), relación de linfocitos a monocitos (LMR), relación de plaquetas a linfocitos (PLR)] se compararon en cada grupo. La PLT y el MPV en las mujeres del grupo prematuro fueron más altos que en las mujeres con amenaza de parto prematuro y el grupo a término. Durante todo el embarazo, la cuenta plaquetaria mostró su nivel más bajo durante el parto. La NLR durante la admisión, fue mayor en el grupo prematuro que en los grupos de parto amenazado prematuro y a término; la PLR fue mayor en el grupo prematuro que en el grupo a término. La NLR aumentó gradualmente durante el embarazo y alcanzó el pico en el grupo a término una semana antes del parto. La NLR alcanzó el pico en los grupos prematuro y amenazado al final del embarazo. Se construyó un modelo de red neuronal artificial de retropropagación (BP) con PLT, MPV, NLR y PLR significativos como valores de importación en el análisis univariado. El AUG (área bajo la curva), utilizando el modelo de evaluación de curva ROC para predecir el riesgo de parto prematuro, fue de 0,819. En conclusión, la elevación de PLT, MPV, NLR y PLR en mujeres embarazadas está relacionada con el parto prematuro espontáneo. El modelo de red neuronal artificial BP tiene cierto valor predictivo para el parto prematuro espontáneo.
\end{abstract}

Received: 30-07-2019 Accepted: 24-01-2020

\section{INTRODUCTION}

Preterm birth has always been a complieated and difficult issue in the field of obstetrics in various countries. According to the World Health Organization survey, preterm birth is the main cause of perinatal morbidity and mortality with an estimated global rate of $18 \%$ (1). The prevention and treatment are the keys to reduce the incidence of preterm births. Therefore, it is particularly important to look for early, non-invasive, sensitive, simple and economical predictive markers (2). Platelet activation has been widely considered in the pathophysiology of inflammation and tumors. Currently, stud-

Vol. 61(1): 28 - 38, 2020 
ies have discussed platelet parameters as inflammatory markers and anti-inflammatory efficacy indicators of various diseases, such as systemic lupus erythematosus, inflammatory bowel disease, rheumatoid arthritis, etc. $(3,4)$. In recent years, the literature has pointed out that maternal NLR, LMR, PLR and other traditional inflammatory indicators can more accurately predict the occurrence of preterm birth compared with other traditional inflammatory indicators (5). But at present, there are few related studies, and the sample size is small.

The mean platelet count decreased monotonically in a manner consistent with the increase in blood volume during pregnancy (6). The total white blood cell count in the first trimester of pregnancy increased and remained elevated, with neutrophil accounting for the change. The absolute neutrophil count during pregnancy was almost twice as high as that of the same postpartum woman (5.76 vs. $3.13 \times 10-3$, but the number of eosinophil granulocyte and basophil granulocyte declined (7).

The BP artificial neural network is a kind of mathematical model which imitates the behavior characteristics of animal neural network for information processing, and it is widely used in the prediction of results. In 2006, Catley et al. (8) first applied the artificial neural network to the prediction of the risk of preterm birth in high-risk pregnant women. The purpose of this study was to investigate the correlation between platelet, leukocyte parameters and spontaneous preterm birth by retrospective analysis, and to evaluate the predictive value of BP artificial neural network model for spontaneous preterm birth.

\section{PATIENTS AND METHODS}

From September 2016 to August 2018, a total of 1,050 single embryo pregnant women taken from the Records Room, Fujian Medical University Union Hospital, Fujian, China, were selected as research subjects and subdivided into three groups. Preterm birth group: 350 cases of pregnant and lying-in women with 28 to 37 weeks gestation; threatened preterm delivery group, 350 cases of pregnant and lying-in women who were admitted to the hospital for threatened preterm delivery during pregnancy and delivered at or above 37 weeks; full-term group: 350 cases of pregnant and lying-in women delivered at or above 37 weeks.

Exclusion criteria: (a) iatrogenic preterm delivery; (b) twin or multiple pregnancy; (c) fetal chromosomal abnormalities or structural abnormalities; (d) uterine abnormalities; (e) taking salicylic acid drugs such as aspirin during pregnancy; (f) complications that may affected platelet parameters of pregnant women: pregnancy-induced hypertension, gestational diabetes mellitus, thrombocytopenia in pregnancy, recurrent abortion history, etc.; ( $g$ ) intra-merger surgical and chronic infectious diseases: cardiopulmonary diseases, rheumatic metabolic diseases, hematological diseases, deep venous thrombosis, tuberculosis, urinary system infections, etc.; (h) irregular obstetric examination and incomplete data.

The clinical data of three groups of pregnant and lying-in women were collected through hospital electronic medical records, including: (a) general conditions: age, education level, height, admission body mass and body mass index (BMI), the number of pregnancies, parity, gestational weeks of delivery, etc.; (b) laboratory parameters for: early preǵnancy (0-13 weeks), mid-pregnancy (14-27 weeks), late pregnancy ( $\geq 28$ weeks, excluding 1 week before delivery), platelet parameters (PLT, MPV, PCT, PDW) and white blood cell parameters (WBC, NLR, LMR, PLR) at admission and during delivery (1 week before delivery).

The clinical data of the three groups were analyzed retrospectively, and the platelet parameters and leukocyte parameters of the three groups were compared. Determination of platelet and leukocyte parameters: PLT [normal value, $125-350 \times 10^{9} / \mathrm{L}$ ], MPV [normal value, 7.2-12 fL], PCT [normal value, 0.11-0.28\%], PDW [normal value, 9-17 
fL], neutrophil count [normal value ,1.8$6.3 \times 10^{9} / \mathrm{L}$ ], lymphocyte count [normal value, $1.1-3.2 \times 10^{9} / \mathrm{L}$ ], monocyte count [normal value, $0.1-0.6 \times 10^{9} / \mathrm{L}$ ] were detected by an automatic five-classification hematology analyzer (LH750, Beckman, US) (9-11). In order to determine the changes in platelet and leukocyte parameters during pregnancy and childbirth, only the first relevant parameter was selected for each woman at each time period.

Diagnostic criteria: The diagnostic criteria for preterm birth refer mainly to the Guidelines for Clinical Diagnosis and Treatment of Preterm Birth (2014) (12): The birth weight of the newborn is $\geq 1000 \mathrm{~g}$ for babies born between 28 weeks and less than 37 weeks of gestation. Diagnostic eriteria for threatened preterm delivery (12): (a) The gestation beyond 28 weeks but less than 37 weeks, and regular uterine contractions occur 4 times every 20 minutes or 8 times every 60 minutes; (b) Cervical canal shortening: $<2.5 \mathrm{~cm}$. (c) Pre-labour rupture of membranes.

BP artificial neural network model construction: Based on the basic principles and methods of artificial neural network, a 3-layer BP artificial neural network was built by Tensor flow in this study to consider the value of platelet and leukocyte parameters in predicting preterm birth. The data of 1050 cases were randomly divided into a training group and a test group according to the ratio of $2: 1$. Among them, 700 cases were used to input BP neural network model for training in the training group, and 350 cases were used to test the accuracy of BP neural network in the test group.

Statistical analysis: The SPSS 23.0 software was used for statistical analysis. The measurement data obeying normal distribution were expressed as mean ( $\bar{x} \pm$ SD). One-way ANOVA or Kruskal-Wallis test were selected for comparison among the three groups. Two-factor repeated measurement variance analysis was used to compare the trend of platelet count and NLR during pregnancy. Qualitative data were expressed by frequencies and percentages. Chi-square test, Fisher exact probability or rank sum test were used to test the difference between groups. The predictive ability of the BP artificial neural network model was described by plotting the area under the ROC curve (AUC). Differences were statistically significant when $\mathrm{p}<0.05$. The exact time for training and testing the neural network was the same after the medical examination.

\section{RESULTS}

\section{General data comparison}

There was no significant differences in age, education level, BMI at admission, number of pregnancies and number of births among the three groups. Age and the incidence of preterm birth history, pre-labour rupture of membranes and searred uterus in the preterm delivery group was higher than those of the full-term group. The incidence of scarred uterus in threatened preterm delivery group was $19.1 \%$, higher than that in full-term and preterm delivery groups, as shown in Table I.

\section{Comparison of platelet parameters}

Compared with the full-term group and threatened preterm group, PLT and MPV in the preterm delivery group were increased, PDW was decreased, and PCT showed no significant difference among the three groups (Tables II and III). The platelet counts in the first trimester (mean 11 weeks of pregnancy), the second trimester (mean 24 weeks of pregnancy) and the third trimester (mean 33 weeks of pregnancy) were $(235.79+46.69)$ $\times 10^{9} / \mathrm{L}, \quad(221.87+44.57) \times 10^{9} / \mathrm{L} \quad$ and $(212.79+49.83) \times 10^{9} / \mathrm{L}, \quad$ respectively. Throughout pregnancy, platelet count showed a decreasing trend, and reached the lowest number at childbirth $(211.28+50.66)$ $\times 10^{9} / \mathrm{L}$. The platelet count in the preterm delivery group was higher than that in the final full-term delivery group, as shown in Fig. 1. 
TABLE I

COMPARISON OF GENERAL INFORMATION AND RISK FACTORS

\begin{tabular}{|c|c|c|c|c|}
\hline Group & Full-term $(n=350)$ & $\begin{array}{l}\text { Threatened preterm } \\
\text { delivery }(\mathrm{n}=350)\end{array}$ & $\begin{array}{l}\text { Preterm delivery } \\
\quad(\mathrm{n}=350)\end{array}$ & $\mathrm{P}$ \\
\hline Age(years) & $29.37 \pm 3.83$ & $29.58 \pm 4.23$ & $29.64 \pm 4.32$ & NS \\
\hline \multicolumn{5}{|l|}{ Education } \\
\hline High school and below & $72(20.57 \%)$ & $47(13.43 \%)$ & $85(24.29 \%)$ & \multirow{3}{*}{ NS } \\
\hline Bachelor or junior college & $248(70.86 \%)$ & $290(82.86 \%)$ & $235(67.14 \%)$ & \\
\hline Postgraduate and above & $30(8.57 \%)$ & $13(3.71 \%)$ & $30(8.57 \%)$ & \\
\hline $\operatorname{BMI}\left(\mathrm{kg} / \mathrm{m}^{2}\right)$ & $25.88 \pm 2.86$ & $25.70 \pm 2.67$ & $25.20 \pm 3.33$ & NS \\
\hline \multicolumn{5}{|l|}{ Gravidity } \\
\hline$<3$ & $282(80.6 \%)$ & $290(82.9 \%)$ & $299(85.4 \%)$ & \multirow{2}{*}{ NS } \\
\hline$\geq 3$ & $68(19.4 \%)$ & $60(17.1 \%)$ & $51(14.6 \%)$ & \\
\hline \multicolumn{5}{|l|}{ Parity } \\
\hline$<2$ & $344(98.3 \%)$ & $341(97.4 \%)$ & $347(99.1 \%)$ & \multirow{2}{*}{ NS } \\
\hline$\geq 2$ & $6(1.7 \%)$ & $6(1.7 \%)$ & $6(1.7 \%)$ & \\
\hline Weeks of gestation & $39.45 \pm 1.05$ & $39.93 \pm 1.66$ & $34.82 \pm 2.03^{\mathrm{be}}$ & $<0.01^{\mathrm{a}}$ \\
\hline Assisted reproduction & $7(2.0 \%)$ & $5(1.4 \%)$ & $9(2.6 \%)$ & NS \\
\hline History of preterm delivery & $4(1.1 \%)$ & $8(2.3 \%)$ & $21(6.0 \%)^{\mathrm{bc}}$ & $<0.01^{\mathrm{a}}$ \\
\hline $\begin{array}{l}\text { Pre-labour rupture of } \\
\text { membranes }\end{array}$ & $128(36.6 \%)$ & $115(32.9 \%)$ & $194(55.4 \%)^{\mathrm{be}}$ & $<0.01^{\mathrm{a}}$ \\
\hline Searred uterus & $4(1.1 \%)$ & $67(19.1 \%)^{\mathrm{b}}$ & $38(10.9 \%)^{\mathrm{bc}}$ & $<0.01^{\mathrm{a}}$ \\
\hline
\end{tabular}

${ }^{a}$ contrast for whole $\mathrm{P}<0.05$; $^{\mathrm{b}}$ compared with the full-term group, $\mathrm{P}<0.05 ;{ }^{\mathrm{c}} \mathrm{P}<0.05$ compared with the group with preterm labor.

TABLE II

COMPARISON OF PLATELET PARAMETERS WHEN TWO WEEKS AFTER DELIVERY

\begin{tabular}{lcccc}
\hline Group & PLT $\left(\times 10^{9}\right)$ & MPV $(\mathrm{fL})$ & PCT $(\%)$ & PDW $(\%)$ \\
\hline Full-term & $207.89 \pm 51.67^{*}$ & $10.82 \pm 0.92$ & $0.22 \pm 0.05$ & $12.93 \pm 2.24$ \\
Threatened preterm delivery & $214.88 \pm 48.48$ & $10.42 \pm 0.98^{\mathrm{b}}$ & $0.22 \pm 0.05$ & $12.11 \pm 2.34^{\mathrm{b}}$ \\
Preterm birth & $220.99 \pm 51.55^{\mathrm{bc}}$ & $11.48 \pm 1.03^{\mathrm{be}}$ & $0.22 \pm 0.05$ & $12.26 \pm 2.35^{\mathrm{b}}$ \\
P & $<0.01^{\mathrm{a}}$ & $<0.001^{\mathrm{a}}$ & 0.092 & $<0.001^{\mathrm{a}}$ \\
\hline
\end{tabular}

*Data are expressed as mean \pm SD.

${ }^{\mathrm{a}}$ Comparison with the total population $\mathrm{P}<0.05$; ${ }^{\mathrm{b}}$ compared with the full-term group, $\mathrm{P}<0.05$; ${ }^{\mathrm{c}}$ compared with the group with preterm labor, $\mathrm{P}<0.05$. 
TABLE III

COMPARISON OF PLATELET CHANGES DURING PREGNANCY

\begin{tabular}{lccccc}
\hline \multicolumn{1}{c}{ Group } & First trimester & Second trimester & Third trimester & Delivery & $\mathrm{P}$ \\
\hline $\begin{array}{l}\text { Full-term } \\
\begin{array}{l}\text { Threatened } \\
\text { preterm delivery }\end{array}\end{array}$ & $238.87 \pm 47.44^{*}$ & $222.47 \pm 46.41$ & $203.68 \pm 48.65$ & $206.85 \pm 50.54$ & $\mathrm{P}<0.001$ \\
Preterm delivery & $238.56 \pm 45.58$ & $216.99 \pm 42.51$ & $214.34 \pm 48.01$ & $207.99 \pm 48.49$ & $\mathrm{P}<0.001$ \\
\hline
\end{tabular}

*Data are expressed as mean \pm SD x $10{ }^{9} \mathrm{~L}$.

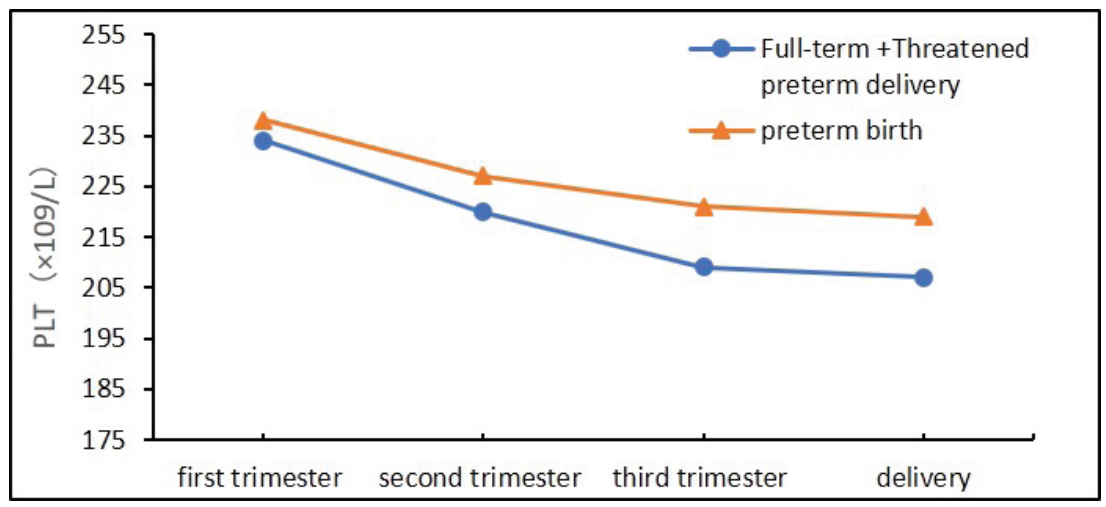

Fig. 1. Trend of NLR during pregnancy.

\section{Comparison of leukocyte parameters}

Compared with the full-term group and threatened preterm group, the NLR and PLR in the preterm delivery group were higher. There were no significant differences in LMR and WBC among the three groups (Table IV). The NLR gradually increased during pregnancy and peaked during delivery in the full-term group, while it peaked in late pregnancy in the threatened preterm and preterm delivery groups and declined during delivery. Compared with the other two groups, the NLR in preterm delivery group in early pregnancy, late pregnancy and delivery period was higher (Table V). The trend of the NLR during pregnancy in the three groups of pregnant women is shown in Fig. 2.

\section{BP artificial neural network model}

The four statistically significant parameters PLT, MPV, NLR and PLR were selected as input layer neurons in univariate analysis, and whether they were premature or not as output layer neurons. The weights of PLT, MPV, NLR and PLR in BP artificial neural network model were calculated to be 1.77 , $2.46,1.89$ and 0.72 , respectively. The results showed that MPV had the greatest influence on the prediction of preterm delivery, NLR was the second, PLT was the third and PLR was the last. The model was analyzed by a ROC curve. The AUC was calculated to be 0.817 and the diagnostic threshold was 0.491 . When the diagnostic threshold is 0.491 , the sensitivity, specificity and consistency of BP artificial neural network in the diagnosis of preterm labor are 69.8\%, 85.7\% and $80.9 \%$, respectively (Fiǵ. 3).

\section{DISCUSSION}

\section{Spontaneous preterm delivery and changes of platelet parameters}

The study showed that during the first three months of a normal pregnancy, platelet counts drop and reached a minimal level 
TABLE IV

COMPARISON OF LEUKOGYTE PARAMETERS IN THREE GROUPS OF PREGNANT WOMEN

\begin{tabular}{lcccc}
\hline \multicolumn{1}{c}{ Group } & NLR & PLR & LMR & WBC \\
\hline Full-term & $4.67 \pm 2.45^{*}$ & $134.13 \pm 46.37$ & $2.62 \pm 0.78$ & $10.27 \pm 3.40$ \\
Threatened preterm delivery & $5.16 \pm 2.24^{\mathrm{b}}$ & $142.65 \pm 47.19^{\mathrm{b}}$ & $2.48 \pm 0.83$ & $10.40 \pm 2.55$ \\
Preterm birth & $6.43 \pm 3.77^{\mathrm{bc}}$ & $143.42 \pm 52.35^{\mathrm{b}}$ & $2.63 \pm 1.15$ & $11.21 \pm 3.14$ \\
P & $<0.001^{\mathrm{a}}$ & $0.05^{\mathrm{a}}$ & NS & NS \\
\hline
\end{tabular}

Values *Data are expressed as mean \pm SD.

${ }^{\mathrm{a}}$ contrast for whole $\mathrm{P}<0.05 ;{ }^{\mathrm{b}}$ compared with the full-term group, $\mathrm{P}<0.05 ;{ }^{\mathrm{c}}$ compared with the group with preterm labor, $\mathrm{P}<0.05$.

TABLE $\mathrm{V}$

COMPARISON OF NLR CHANGES DURING PREGNANGY

\begin{tabular}{cccccc}
\hline Group & First trimester & Second trimester & Third trimester & Delivery & $\mathrm{P}$ \\
\hline Full-term & $3.10 \pm 1.02 *$ & $3.92 \pm 1.25$ & $4.65 \pm 2.45$ & $4.88 \pm 2.84$ & $\mathrm{P}<0.001$ \\
$\begin{array}{c}\text { Threatened } \\
\text { preterm delivery }\end{array}$ & $3.28 \pm 1.29$ & $4.04 \pm 1.36$ & $5.21 \pm 2.26$ & $4.65 \pm 2.44$ & $\mathrm{P}<0.001$ \\
Preterm birth & $3.42 \pm 1.28$ & $4.09 \pm 1.39$ & $6.04 \pm 2.15$ & $5.77 \pm 3.46$ & $\mathrm{P}<0.001$ \\
\hline
\end{tabular}

*Data expressed as mean $\pm \mathrm{SD}$.

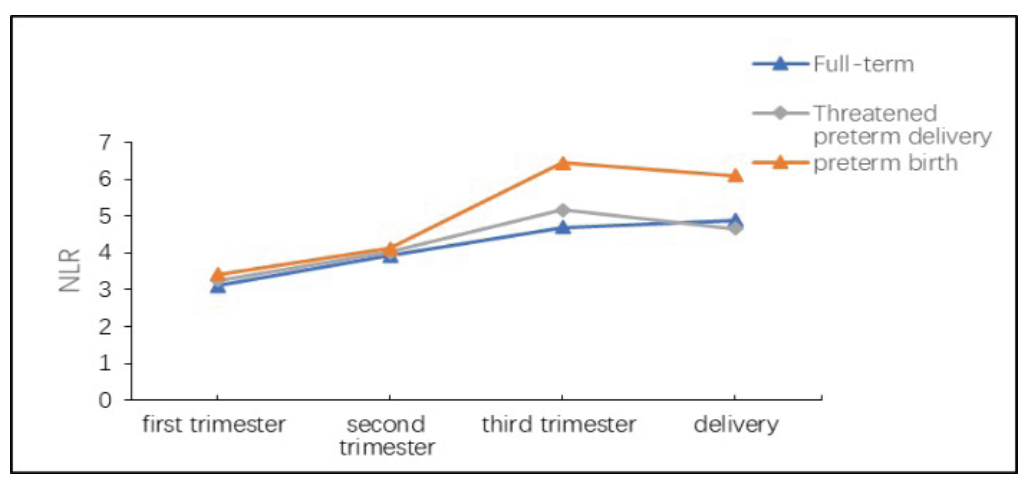

Fig. 2. Trend of NLR durinǵ preǵnancy.

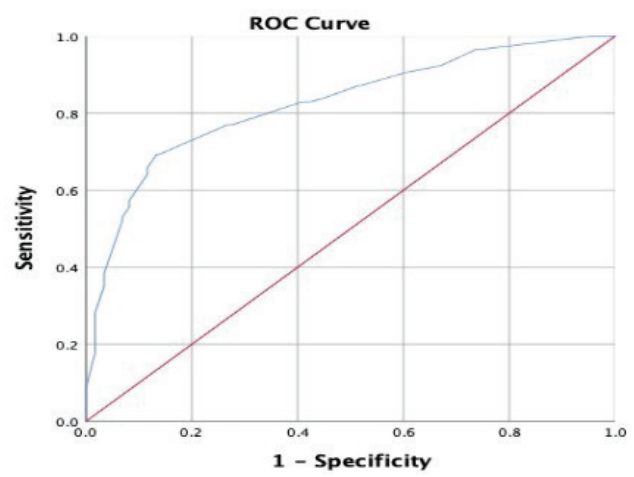

Fig. 3. ROC curve of BP artificial neural network predicting spontaneous preterm birth. 
at birth. In addition to physiological platelet dilution, post-pregnancy splenomegaly may also lead to an increase in platelet aggregation, which may also lead to a decrease in the platelet count. In normal, non-pregnant women, one-third of circulating platelets briefly accumulate in the splenic sinus during low-velocity circulation. Because placental circulation is similar to that of the spleen, platelets may accumulate in the villous cavity of the placenta, leading to further thrombocytopenia $(13,14)$.

Platelet activation has been widely implicated in the pathophysiology of inflammation and malignant tumors. A platelet indicator such as the mean platelet volume is considered as a marker of inflammation (12, $15,16)$. In obstetrics, the changes of platelet parameters were correlated with gestational hypertension, gestational diabetes mellitus and recurrent abortion diseases $(17,18)$. Therefore, in this study, we excluded the above-mentioned complications related to internal medicine, surgery and obstetrics in order to exclude the factors that interfere with platelet parameters as far as possible. In inflammatory response, platelets migrate to specific sites and regulate their functions by changing their morphology and releasing bioactive substances. This study found that PLT and MPV of pregnant women in the preterm delivery group were higher than those in threatened preterm delivery group and full-term group, which was consistent with the results of Isik $\mathrm{H}$ et al. (19). The results showed that PLT of pregnant women in the preterm and full-term delivery groups were different, and that the PLT elevation could be used as a predictor of preterm birth. Inflammation is the primary risk factor for preterm birth. Under inflammatory conditions, the uterine cavity produces inflammatory cytokines that enter the maternal circulation. The excessive production of eytokines such as interleukin (IL) -4, IL-6 and tumor necrosis factor (TNF) interferes with the production of megakaryocytes, which leads to the increase of platelet release from bone mar- row, thus in turn affecting changes in platelet parameters (20)].

\section{Spontaneous premature birth and changes of leukocyte parameters}

It was well-known that spontaneous preterm labor was highly associated with the increase of proinflammatory factors in the monocytes of maternal blood (21), and that NLR was an inflammatory marker with high sensitivity and specificity (22). The results of this study showed that the NLR in the fullterm group increased from early pregnancy and reached its peak in late pregnancy or childbirth. This change was beneficial for the mother to strengthen self-defense and protect the fetus and herself from infection; due to the characteristic of NLR as an available biomarker to convey the inflammatory conditions after various treatments or medication.

Inflammatory markers are considered as potential predictors of preterm birth. Traditional inflammation markers include white blood cell count, CRP, procalcitonin and so on. Because white blood cell counts will increase physiologically during pregnancy and are vulnerable to stress or physical activity and other factors, the sensitivity and specificity of using these indicators alone is limited. IL-6, IL-8 and TNF can also be used as markers for predicting preterm delivery, but they are not widely used because of the high cost of detection (20). Some clinical studies have shown that NLR can be used as a prognostic indicator in a variety of infectious diseases and tumors $(20,23)$. In recent years, some scholars have proposed that NLR and PLR as new inflammation indicators may predict the occurrence of preterm birth (24). Gezer C. et al. (25) found that there were significant differences in NLR between preterm and full-term births, which were similar to the results in this study. NLR represents the balance between inflammatory activators and inflammatory regulators. The higher the NLR, the more obvious the imbalance, suggesting the more serious the inflammation 
in the body. In addition, Jung et al. (26), found that pregnant women with high NLR had an increased risk of preterm birth following emergency cerclage. This study suggested that the maternal inflammation reaction existed when NLR increased, and NLR might eventually increase the occurrence of adverse pregnancy outcomes such as prelabour rupture of membranes by affecting placental and placental membrane integrity.

\section{Premature birth prediction model based on a BP artificial neural network}

There are many ways to predict preterm birth, such as ultrasound measurement of cervical tube length and fetal fibronectin screening, but they can only be used to predict the imminent preterm birth within 7 to 14 days. The parameters of platelets and leukocytes can be obtained only by routine blood test. It is simple, cheap and has good clinical practicability. Isik et al. (19) reported that the best cut-off value for predicting preterm delivery of PLT was $234 \times 10^{3} / \mathrm{mm}^{3}$ (sensitivity $81.0 \%$, specificity $71.0 \%$ ). Studies of Ekin A. et al. $(27,28)$ have shown that high NLR is an independent predictor of preterm birth (OR 1.41, 95\% CI 1.32-1.51). Strengthening the monitoring of platelet parameters and leukocyte parameters in clinical work is helpful to the early detection and diagnosis of spontaneous preterm birth.

The artificial neural network has high reliability and accuracy by integrating and analyzing a large number of characteristic parameters of disease. It has achieved some results in expert diagnostic systems of disease and prediction of risk and survival time of cancer patients. Vinken et al. (29, 30) proved that the artificial neural network has good classification and recognition efficiency in the prediction of preterm birth. This research innovatively combines platelet and leukocyte parameters with the BP artificial neural network model, jumps out of the prediction model limited to biomarkers, uses artificial intelligence analysis system and interdisciplinary cooperation, in order to build a better and more effective prediction model for preterm delivery. In this study, the AUC of the ROC curve predicted by the BP artificial neural network system was 0.817 , which proves that the model has a better predictive value for preterm labor. In the future, we can also use clinical large data to train the neural network model continuously, increase the predictive efficiency, and conduct an etiological shunt from the early stage, which will help to overcome the maternalfetal medicine problem of premature birth.

As a conclusion, PLT, MPV, PLR and NRL can be used as predictors of spontaneous preterm birth. The artificial neural network model has certain predictive value for spontaneous preterm birth. In clinical work, we should pay close attention to the relevant indicators, which is helpful to monitor the occurrence and development of preterm birth.

\section{FUNDING}

Fujian Science and Technology Project (2018Y0005) and Fujian Medical Innovation Subject (2017-CX-11).

\section{REFERENCES}

1. He C, Liu L, Chu Y, Perin J, Dai L, Li X, Miao L, Kang L, Li Q, Scherpbier R, Guo S, Rudan I, Song P, Chan KY, Guo Y, Black RE, Wang Y, Zhu J. National and subnational all-cause and cause-specific child mortality in China, 1996-2015: a systematic analysis with implications for the Sustainable Development Goals. Lancet Glob Health 2017;5(2):e186-e97.

2. Aung MT, Yu Y, Ferguson KK, Cantonwine DE, Zeng L, MeElrath TF, Pennathur S, Mukherjee B, Meeker JD. Prediction and associations of preterm birth and its subtypes with eicosanoid enzymatic pathways and inflammatory markers. Sci Rep 2019;9(1):17049.

3. Gasparyan AY, Ayvazyan L, Mikhailidis DP, Kitas GD. Mean platelet volume: a link between thrombosis and inflammation? Curr Pharm Des 2011;17(1):47-58.

4. Akpinar I, Sayin MR, Gursoy YC, Karabag T, Kucuk E, Buyukuysal MC, Aydin M, Haznedaroglu IC. Plateleterit. A platelet marker associated with saphenous vein graft disease. Herz 2014;39(1):142-148. 
5. Kim MA, Lee YS, Seo K. Assessment of predictive markers for placental inflammatory response in preterm births. PLoS One 2014;9(10):e107880.

6. Pitkin RM, Witte DL. Platelet and leukocyte counts in pregnancy. JAMA 1979; 242(24):2696-2698.

7. Okoye HC, Madu AJ, Korubo K, Efobi C, Eze OE, Obodo O, Okereke K, Ilechukwu G. Correlates of neutrophil/lymphocyte, platelet/lymphocyte, and platelet/neutrophil ratios of neonates of women with hypertensive disease of pregnancy with neonatal birth outcomes. Hypertens Preǵnancy 2019;38(2):105-110.

8. Catley C, Frize M, Walker CR, Petriu DC. Predicting high-risk preterm birth using artificial neural networks. IEEE Trans Inf Technol Biomed 2006;10(3):540-549.

9. Bain BJ, Enǵland JM. Normal haematological values: sex difference in neutrophil count. BMJ 1975;1(5953):306-309.

10. Tillack K, Naegele M, Haueis C, Schippling S, Wandinger KP, Martin R, Sospedra M. Gender differences in circulating levels of neutrophil extracellular traps in serum of multiple sclerosis patients. J Neuroimmunol 2013;261(1-2):108-119.

11. Christoforaki V, Zafeiriou Z, Daskalakis G, Katasos T, Siristatidis C. First trimester neutrophil to lymphocyte ratio (NLR) and preǵnancy outcome. J Obstet Gynaecol 2020;40(1):59-64.

12. Schmitz T, Sentilhes L, Lorthe E, Gallot D, Madar H, Doret-Dion M, Beucher G, Charlier C, Cazanave C, Delorme P, Garabédian C, Azria E, Tessier V, Sénat MV, Kayem G. Preterm premature rupture of membranes: CNGOF Guidelines for clinical practice - Short version. Gynecol Obstet Fertil Senol 2018;46(12):998-1003.

13. Zhang $\mathbf{H}$, Zhang $\mathrm{Y}$, Wang $Z$, Yan J. Platelet count and mean platelet volume predict atypical pre-eclampsia. Preǵnancy Hypertens 2019;18:29-34.

14. Madar H. Management of preterm premature rupture of membranes (except for antibiotherapy): CNGOF preterm premature rupture of membranes guidelines. Gynecol Obstet Fertil Senol 2018;46(12):1029-1042.

15. Kohli S, Isermann B. Placental hemostasis and sterile inflammation: New insights into gestational vascular disease. Thrombosis Res 2017;151 Suppl 1:S30-S33.

16. Korniluk A, Koper-Lenkiewiez OM, Kaminska J, Kemona H, Dymicka-Piekarska V. Mean platelet volume (MPV): new perspectives for an old marker in the course and prognosis of inflammatory conditions. Mediators Inflamm 2019;2019:9213074.

17. Aynioĝlu O, Isik H, Sahbaz A, Harma MI, Isik M, Kokturk F. Can plateleterit be a marker for recurrent pregnancy loss? Clin Appl Thromb Hemost 2016;22(5):447-452.

18. Sahbaz A, Cicekler H, Aynioglu O, Isik H, Ozmen U. Comparison of the predictive value of plateleterit with various other blood parameters in gestational diabetes development. J Obstet Gynaecol 2016;36(5):589593.

19. Isik H, Aynioglu O, Sahbaz A, Arikan I, Karcaaltincaba D, Sahin H, Koroglu M. Can plateletcrit, an underestimated platelet parameter, be related with preterm labour? J Obstet Gynaecol 2015;35(7):676-680.

20. Nadeau-Vallee M, Obari D, Palacios J, Brien ME, Duval C, Chemtob S, Girard S. Sterile inflammation and pregnancy complications: a review. Reproduction (Cambridǵe, Enǵland) 2016;152(6):R277-R292.

21. Pawelezyk E, Nowicki BJ, Izban MG, Pratap S, Sashti NA, Sanderson M, Nowicki S. Spontaneous preterm labor is associated with an increase in the proinflammatory signal transducer TLR4 receptor on maternal blood monocytes. BMC Preǵnancy Childbirth 2010;10:66.

22. Davis BK, Wen H, Ting JP. The inflammasome NLRs in immunity, inflammation, and associated diseases. Annu Rev Immunol 2011;29:707-735.

23. Xiao WK, Chen D, Li SQ, Fu SJ, Peng BG, Liang LJ. Proǵnostic siǵnificance of neutrophil-lymphocyte ratio in hepatocellular carcinoma: a meta-analysis. BMC Cancer 2014;14:117.

24. Daglar HK, Kirbas A, Kaya B, Kilineoglu F. The value of complete blood count parameters in predicting preterm delivery. Eur Rev Med Pharmacol Sci 2016;20(5):801-805.

25. Gezer C, Ekin A, Solmaz U, Sahingoz Yildirim AG, Dogan A, Ozeren M. Identification of preterm birth in women with threatened preterm labour between 34 and 
37 weeks of gestation. J Obstet Gynaecol 2018;38(5):652-657.

26. Jung EY, Park KH, Lee SY, Ryu A, Joo JK, Park JW. Predicting outcomes of emergency cerclage in women with eervical insufficiency using inflammatory markers in maternal blood and amniotic fluid. Int J Gynaecol Obstet 2016;132(2):165-169.

27. Ekin A, Gezer C, Kulhan G, Avei ME, Taner CE. Can platelet count and mean platelet volume during the first trimester of pregnancy predict preterm premature rupture of membranes? J Obstet Gynaecol Res 2015;41(1):23-28.

28. Romero R, Miranda J, Chaiworapongsa T, Korzeniewski SJ, Chaemsaithong P,
Gotsch F, Dong Z, Ahmed AI, Yoon BH, Hassan SS, Kim CJ, Yeo L. Prevalence and clinical significance of sterile intraamniotic inflammation in patients with preterm labor and intact membranes. Am J Reprod Immunol (New York, NY: 1989) 2014;72(5):458-474.

29. Hosny A, Aerts H. Artificial intelligence for global health. Science (New York, NY) 2019;366(6468):955-956.

30. Vinken MP, Rabotti C, Mischi M, Oei SG. Accuracy of frequency-related parameters of the electrohysterogram for predicting preterm delivery: a review of the literature. Obstet Gynecol Surv 2009;64(8):529. 541. 